\title{
O TŁUMACZENIU KOMIZMU JĘZYKOWEGO NA PRZYKŁADZIE POLSKICH PRZEKŁADÓW GIER JĘZYKOWYCH W WINNIE-THE-POOH I THE HOUSE AT POOH CORNER A. A. MILNE'A
}

\footnotetext{
Zarys treści. Artykuł przybliża pojęcie gry językowej i określa jej funkcję w omawianych utworach jako środka służącego osiągnięciu komizmu językowego. Wymieniono tu przyczyny trudności przekładu tekstów operujących dowcipem słownym. Zagadnienie ilustrują przykłady semantycznych gier językowych występujących w utworach A. A. Milne'a wraz z ich przekładami na język polski. Autorka zwraca uwagę na możliwości oraz wynikające ze specyfiki języka docelowego trudności z przekładem poszczególnych gier. Na zakończenie dokonuje oceny przedstawionych strategii translatorskich z punktu widzenia współczesnej teorii przekładu.
}

$\mathrm{M}$ echanizm gry językowej w tekstach różnego typu i przeznaczenia, zawsze zajmujący badaczy literatury, przyciąga także uwagę językoznawców. Gra językowa, ze względu na stopień trudności jej przekładu, jest także zjawiskiem interesującym z punktu widzenia translatoryki. W pracach poświęconych zagadnieniom przekładu często wyrażana jest opinia, że gry językowe stanowią szczególnie trudne wyzwanie dla tłumacza, a w wielu przypadkach są wręcz na granicy przekładalności. Agnieszka Koroniejenko zwraca uwagę na fakt, że nawet ci autorzy podręczników teorii przekładu, którzy wzbraniają się mówić o absolutnej nieprzekładalności, używają na przykład pojęcia „względna nieprzekładalność” wszędzie tam, gdzie ważną rolę w tekście odgrywają zabawy językowe, kalambury, żonglowanie wyrazami lub ich częściami, gdzie pojawiają się idiomy (Koroniejenko 1995: 157). Skrajne stanowisko w tym względzie reprezentuje Piotr Fast, który 
wyrażenia oparte na grze słów określa jako „radykalnie nieprzetłumaczalne" (Fast 1991: 24).

Termin gra językowa, mimo iż posługują się nim przedstawiciele zarówno językoznawstwa, jak i literaturoznawstwa, nie został dotąd sprecyzowany w żadnej z tych dyscyplin. Najogólniej ujmuje się go jako zespół zabiegów stylistycznych, w różnym stopniu przekraczających reguły kodu językowego w warstwie strukturalnej i semantycznej. Ewa Jędrzejko wskazuje, że zasadą tak rozumianej gry językowej jest transformacja lub modyfikacja elementów struktury formalnej i semantycznej tekstu. Sygnałem gry w tekście literackim jest więc każde sfunkcjonalizowane naruszenie (ilościowe i jakościowe) zwykłych reguł użycia i budowy znaku z mocy kodu językowego (Jędrzejko 1997: 67).

Należy jednak podkreślić, że pojęcie „gra językowa” odnosi się wyłącznie do świadomej manipulacji językiem, nie dotyczy zaś mimowolnej niezręczności językowej osoby tworzącej tekst, zwyczajnych niezamierzonych błędów w wypowiedzi, nawiasem mówiąc często wywołujących rozbawienie u odbiorców.

Gra językowa często służy jako narzędzie komizmu językowego. W swoją grę, której tworzywem jest język, autor wciąga czytelnika. Celem jego gry z odbiorcą jest wywołanie efektu komicznego, wywołanie rozbawienia u czytającego. Czytelnik - rodzimy użytkownik danego języka - zna rządzące językiem reguły i spodziewa się pewnych zachowań językowych. Wypowiedź niezgodna z oczekiwaniami odbiorcy, naruszająca reguły kodu, zaskakuje i może bawić. Ta rozbieżność między oczekiwaniem odbiorcy a realizacją wypowiedzi wynikająca ze świadomej manipulacji autora systemem języka stanowi mechanizm komizmu językowego w tekstach operujących grą językową.

Ewa Teodorowicz-Hellman wyraża pogląd, że tłumaczenie komizmu językowego sprawia najwięcej trudności w przekładzie. Żart, dowcip, zabawa słowem w języku oryginału nie zawsze znajdują bowiem ekwiwalent w języku przekładu. Z powodu różnic systemowych między dwoma językami tłumacz nie może stosować tych samych zabiegów w celu utworzenia dowcipu językowego. Tak więc tzw. granice przekładalności bardzo wyraźnie dają znać o sobie właśnie przy przekładzie komizmu (Teodorowicz-Hellman 1997: 210).

Interesujący przykład użycia gry językowej jako źródła komizmu w literaturze dla dzieci stanowią Winnie-the-Pooh i The House at Pooh Corner Alexandra Alana Milne’a. Gra językowa przybiera w nich wiele różnych postaci, występuje zarówno w narracji, jak i w wypowiedziach bohaterów. 
Milne stosuje różnorodne rodzaje gier językowych, łamie reguły obowiązujące na wielu płaszczyznach języka - składniowej, semantycznej, leksykalnej, fonetycznej i graficznej. Chciałabym omówić jeden z typów tworzonych przez niego gier językowych, a mianowicie gry funkcjonujące w sferze znaczeń oraz rozwiązania zastosowane przy ich przekładzie na język polski. (Obie książki przełożone zostały na język polski przez Irenę Tuwim, a Winnie-the-Pooh doczekała się również drugiego przekładu autorstwa Moniki Adamczyk). Przy opisie strategii translatorskich chciałabym dodatkowo zwrócić uwagę na możliwości oraz wynikające ze specyfiki języka docelowego trudności z przekładem omawianych gier.

Pierwszym ze zjawisk z dziedziny semantyki, które leży u podstaw semantycznych gier językowych, jest wieloznaczność jednostek leksykalnych. Terminu wieloznaczność używam dla określenia faktu niejednoznaczności wyrazów izolowanych zgodnie z wysuniętym przez Macieja Grochowskiego postulatem odrzucenia tradycyjnego rozróżnienia homonimii i polisemii jako odrębnych faktów językowych. W tradycyjnym ujęciu fakt niejednoznacznościizolowanych wyrazów bywaw dwojaki sposób interpretowany: albo przyjmuje się, że dany wyraz ma więcej niż jedno znaczenie, albo wyróżnia się dwa lub większą liczbę wyrazów o identycznej postaci, z których każdy jest jednoznaczny, ale ma inne znaczenie. Pierwszy sposób interpretacji niejednoznaczności prowadzi do wyróżnienia zjawiska polisemii, a drugi - zjawiska homonimii. Z punktu widzenia synchronicznej semantyki leksykalnej opozycja polisemia-homonimia stanowi bowiem jedynie opozycję odzwierciedlającą różnice w konwencji opisu tego samego zjawiska niejednoznaczności (Grochowski 1982: 72).

Tworzone przez A. A. Milne’a gry językowe, opierające się na wyrazach wieloznacznych, polegają na zestawieniu obu znaczeń danego wyrazu i zaskakującym przejściu od jednego z nich do drugiego. Mechanizm ten ilustrują przykłady:

1. What does the North Pole look like? I suppose it's just a pole stuck in the ground - sure to be a pole, because of calling it a pole, and if it's a pole, well I should think it would be sticking in the ground (Winnie-the-Pooh).

Podjęta przez bohaterów książki wyprawa w poszukiwaniu Bieguna Północnego (North Pole) uznana została przez jej uczestników za zakończoną powodzeniem po tym, jak Puchatek odnalazł leżącą w trawie tyczkę (a pole). 
2. The river [...] had sprawled out of its own bed and was taking up so much room everywhere, that Piglet was beginning to wonder whether it would be coming into his bed soon (Winnie-the-Pooh).

Milne wykorzystuje dwuznaczność wyrazu bed (łóżko i, w odniesieniu do rzeki, koryto).

3. He was fond of it. Attached to it (Winnie-the-Pooh).

Mowa jest o zagubionym ogonie Kłapouchego. Autor używa wyrazu attached, w sposób odsyłający do obu jego znaczeń jednocześnie, a mianowicie więzi emocjonalnej i faktu bycia przymocowanym do czegoś (w tym wypadku za pomocą gwoździa).

Przekład gier językowych wykorzystujących zjawisko wieloznaczności stanowi trudne zadanie, na co zwracają uwagę Teresa Tomaszkiewicz i Alicja Pisarska. Najogólniej rzecz ujmując, trudność tłumaczenia na tym poziomie polega na tym, że jeden leksem może odsyłać do wielu znaczeń, ale niekoniecznie w ten sam sposób, w różnych językach. Zjawisko wieloznaczności jest charakterystyczne dla wszystkich języków, ale nie ma odpowiedniości zakresów znaczeń między jednostkami leksykalnymi różnych języków (Tomaszkiewicz, Pisarska 1996: 93-94). Jeżeli chodzi o przytoczone wcześniej fragmenty oryginału, z taką identycznością zakresów znaczeń zachodzącą pomiędzy jednostkami języka oryginału i przekładu nie mamy do czynienia w przypadku żadnej z gier.

W największym stopniu pokrywają się zakresy znaczeń polskiego i angielskiego wyrażenia, na którym oparta jest gra nr 3. Polski odpowiednik angielskiego wyrazu attached jest tak samo jak on wieloznaczny. Oba wyrazy (attached i przywiązany) odsyłają zarówno do pojęcia więzi emocjonalnej, jak i faktu bycia przytwierdzonym do czegoś. Jednakże wyraz przywiq$z a n y$, w przeciwieństwie do swojego oryginalnego odpowiednika, precyzuje sposób, w jaki jeden przedmiot jest przymocowany do drugiego. Z dalszej części teksu dowiadujemy się natomiast, że Krzyś odnaleziony ogon przybił na miejsce za pomocą gwoździa. Wyraz przywiązany jest więc w tej sytuacji nieadekwatny. W obu polskich przekładach fragment nr 3 przetłumaczony został dosłownie, co spowodowało utratę jego komicznego charakteru w polskiej wersji językowej:

On to bardzo lubił. Był do tego bardzo przywiązany (Tuwim).

Bardzo go lubił. Był do niego przywiązany (Adamczyk). 
W przekładzie fragmentów 1 i 2 polskim tłumaczkom udało się uzyskać zadowalający efekt dzięki zastosowaniu zmienionej gry słów. W przypadku pierwszej gry językowej wykorzystały to, że jeden z członów wyrażenia Biegun Północny w języku polskim jest również wieloznaczny. Jednym $z$ jego znaczeń jest 'półokrągła płoza przy kołyskach, bujanych fotelach, zabawkach'. Mimo iż tego znaczenia pozbawiony jest występujący w oryginale wyraz pole, odwołanie się do elementu dziecięcej zabawki w przekładzie jest wyjątkowo trafnym rozwiązaniem. Pamiętając, że mieszkańcami Stumilowego Lasu są pluszowe zwierzęta, obecność tam bieguna - części starej zabawki - wydaje się naturalna. Przejście od jednego ze znaczeń wyrazu biegun do innego widoczne jest w poniższych zdaniach przekładów:

Krzyś przypatrzył się dobrze drewienku.

- To biegun od mojego drewnianego konia z odłamaną nogą, poznaję! [...] Puchatku, Wyprawa jest zakończona. Znalazłeś Biegun Północny (Tuwim).

Jak wygląda Biegun Pótnocny? [...]

Sądzę, że to po prostu jakiś biegun zgubiony przez konia (Adamczyk).

Taki sam fakt braku zupełnej odpowiedniości znaczeń wyrazów języka oryginału i przekładu, który jednak oddania gry językowej pierwowzoru w języku polskim nie umożliwia całkowicie, zaobserwować można w przypadku pary wyrazów bed i koryto z przykładu drugiego. Zjawisko to umiejętnie wykorzystała Irena Tuwim, zastępując grę językową oryginału w następujący sposób:

Rzeka [...] wystąpiła z koryta i rozlewała się tak szeroko na wszystkie strony, że Prosiaczek zaczynał się zastanawiać, czy nie zaleje ona niedługo jego własnego korytka (Tuwim).

W przekładzie Moniki Adamczyk oryginalna gra oparta na zjawisku wieloznaczności została zastąpiona przez grą językową bazującą na częściowym zewnętrznym podobieństwie wyrazów o różnych znaczeniach. Por.:

Rzeka [...] wystąpiła z łożyska i zajmowała już tyle miejsca, że Prosiaczek zaczął się zastanawiać, czy wkrótce nie dojdzie i do jego łóżeczka (Adamczyk).

Komiczny efekt oryginału został w przekładzie częściowo zatarty, ponieważ wspólna etymologia wyrazów łożysko i łóżeczko, na której opiera się wprowadzona w przekładzie gra, nie jest znana dziecięcemu czytelnikowi. 
Następnym zjawiskiem ze sfery znaczeń, na którym opierają się autorskie gry semantyczne A. A. Milne’a, jest synonimia. Synonimię rozumiem zgodnie z definicją Grochowskiego, czyli jako relację między jednostkami leksykalnymi, których znaczenia całkowicie się pokrywają, a więc są identyczne. Wszelkie różnice między synonimami są różnicami innymi niż semantyczne. Mają one przede wszystkim charakter pragmatyczny i gramatyczny, mogą dotyczyć ponadto ich etymologii (Grochowski 1982: 72-73). Oto przykład gry wykorzystującej zjawisko synonimii:

4. Tigger accidentally knocked over one or two chairs by accident (The House at Pooh Corner).

Wyrażenia accidentally i by accident mają identyczne znaczenie, a mianowicie 'bez zamiaru, woli'. Ich zestawienie stanowi więc niepożądany w języku pleonazm, czyli narusza regułę niepowtarzania treści (tylko pod warunkiem, że został użyty celowo, patrz s. 119, 1. akapit).

Mimo iż w języku docelowym istnieje grupa synonimów o znaczeniu 'bez zamiaru, woli' (np.: nieumyślnie, niechcący, niezamierzenie, nieświadomie), tłumaczka odstąpiła od powtórzenia treści i fragment oryginału zawierający pleonazm zastąpiła konstrukcją semantycznie poprawną. Zastosowanie takiego rozwiązania spowodowało, że w polskim przekładzie brak jest tej gry językowej, a zatem także efektu komicznego Por.:

Tygrys wywrócił niechcący jedno czy dwa krzesła (Tuwim).

Ostatnią grupę zarejestrowanych w materiale semantycznych gier językowych stanowią tzw. poliptotony, czyli zestawienia wyrazów związanych z sobą etymologicznie, będące jednym z rodzajów powtórzenia (Sierotwiński 1986: 183). Wyrazy tworzące poliptoton nie muszą być synonimami. Wykorzystanie poliptotonu do budowy gry językowej ilustrują przykłady:

5. He sat down and thought in the most thoughtful way he could think (Winnie-the-Pooh).

6. "Underneath" said Piglet in an underneath sort of way (The House at Pooh Corner).

Powyższy fragment zawiera dwupłaszczyznową grę językową. Dla uzyskania gry semantycznej A. A. Milne posłużył się grą słowotwórczą. Jednym z członów poliptotonu jest bowiem jego autorski neologizm underneath sort of way. 
Odpowiadające oryginałowi fragmenty polskich przekładów również zawierają poliptotony:

zaczął myśleć w najbardziej zamyślony sposób, w jaki potrafił myśleć (Adamczyk).

zaczął dumać w najbardziej zadumany sposób, jaki tylko możecie sobie wyobrazić (Tuwim).

Poliptoton stworzony przez Irenę Tuwim ma o jeden człon mniej niż jego pierwowzór.

Pod spodem - rzekł Prosiaczek w sposób bardzo podspodni (Tuwim).

Irenie Tuwim udało się odtworzyć w przekładzie obie płaszczyzny oryginalnej gry językowej. Do budowy poliptotonu tłumaczka użyła własnego neologizmu podspodni.

Na zakończenie chciałabym pokrótce ocenić typy rozwiązań translatorskich zastosowanych przy tłumaczeniu omówionych gier językowych na język polski.

Pierwszym zanotowanym w materiale typem strategii translatorskiej jest wierny przekład gry językowej oryginału (np. fragmenty 5 i 6). Wierność w tym przypadku rozumiana jest jako ekwiwalencja względem oryginału, osiągnięta zarówno na poziomie semantycznym, jak i formalnym. Wierność semantyczna oznacza treściową identyczność komunikatu zawartego w oryginale i przekładzie. Natomiast wierność na poziomie formalnym osiągana jest poprzez zastosowanie identycznego jak w pierwowzorze mechanizmu tworzenia gry językowej, oparcie jej na tym samym zjawisku językowym. Słuszność wyboru takiego rozwiązania przekładowego jest moim zdaniem oczywista i nie wymaga komentarza.

W niektórych przypadkach zastosowanie tego typu strategii było niemożliwe z przyczyn niezależnych od tłumacza. Trudności wynikały bowiem $z$ różnic systemowych między językiem oryginału i przekładu. W celu zachowania komizmu języka i scenek, tłumaczki zmuszone były do poszukiwania ekwiwalentów komizmu na innym polu niż autor oryginału. W przypadku gier wykorzystujących zjawisko wieloznaczności, chcąc utworzyć grę językową powstałą na podstawie tego samego, co zastosowany przez A. A. Milne’a, mechanizmu, tłumaczki zmuszone były zrezygnować z semantycznej wierności oryginałowi (np. fragment 1). Takiego typu rozwiązania są powszechnie aprobowane przez krytyków przekładu. Teodoro- 
wicz-Hellman twierdzi nawet, że jeżeli nie da się znaleźć w języku przekładu ekwiwalentu dla oryginalnego dowcipu, wierność wobec oryginału staje się największym wrogiem komizmu (Teodorowicz-Hellman 1997: 211).

Odosobnionym przypadkiem jest rezygnacja w przekładzie z gry językowej oryginału bez jednoczesnego wprowadzenia na jej miejsce gry innego typu (zob. fragment 4). Tłumaczce udało się przekazać informację zawartą w pierwowzorze, a język przekładu jest poprawny, tłumaczenie należy jednak uznać za niepełnowartościowe, ponieważ pozbawione jest charakterystycznego dla oryginału zabarwienia komicznego. W świetle współczesnej teorii przekładu takiego rozwiązania nie można uznać za słuszne. Przy przekładzie komizmu należy bowiem zwrócić uwage przede wszystkim na rezultat, czyli efekt tłumaczenia. Powinien on być taki, aby czytelnik dzięki swojemu poczuciu humoru i swojej kompetencji językowej i intelektualnej mógł odebrać komizm w przekładzie w ten sam lub podobny sposób, jak to czyni czytelnik oryginału (Teodorowicz-Hellman 1997: 210).

\section{Literatura}

Fast, P., 1991, „O granicach przekładalności”, [w:] Przekład artystyczny, t. I: Problemy teorii i krytyki, red. P. Fast, Katowice.

Grochowski, M., 1982, Zarys leksykologii i leksykografii. Zagadnienia synchroniczne, Toruń.

Jędrzejko, E., 1997, „Strategia tekstotwórcza a gry językowe w literackich nazwach własnych", [w:] Gry w języku, literaturze i kulturze, red. E. Jędrzejko i in., Warszawa.

Koroniejenko, A., 1995, „Dlaczego nieprzekładalność jest niemożliwa”, [w:] Między oryginałem a przekładem I, red. J. Konieczna-Twardzikowa i in., Kraków.

Milne, A. A., 2000, Chatka Puchatka. The House At Pooh Corner (wersja dwujęzyczna), przek. I. Tuwim, Warszawa.

Milne, A. A., 1986, Fredzia Phi-Phi, przek. M. Adamczyk, Lublin.

Milne, A. A., 1999, Kubuś Puchatek. Winnie-the-Pooh (wersja dwujęzyczna), przek. I. Tuwim, Warszawa.

Sierotwiński, S., 1986, Słownik terminów literackich, Wrocław.

Teodorowicz-Hellman, E., 1997, „Komizm w przekładzie prozy dla dzieci (Pippi Pończoszanka Astrid Lindgren po polsku)", [w:] Komizm a prze$k ł a d$, red. P. Fast, Katowice. 
Tomaszkiewicz, T., Pisarska, A., 1996, Współczesne tendencje przekładoznawcze, Poznań.

\section{On the translation of linguistic humour on the example of the Polish translations of Winnie-the-Pooh and The House at Pooh Corner by A. A. Milne \\ (summary)}

Translation of linguistic humour is one of the most difficult tasks in translators practice. The differences between languages often make it impossible to use the same mechanism in order to achieve a comical effect in translation. In order to create linguistic jokes in the literary texts, linguistic games are often used. One of linguistic games appearing in Milne's works are semantic games. These are based on synonyms and homonyms, some of them have a form of polyptoton. In the Polish translation of Milne's works three strategies were applied while translating semantic linguistic games. The most appropriate of them is recreating the original game in the language of the translation. Another solution is replacing the semantic game with a linguistic game of a different kind. In the translation of some of the games based on homonyms the sense of the original text had to be altered. Finally, some of the linguistic games were omitted in translation. This strategy should be recognized as inappropriate, because it makes the original text lose its comical character in translation. 